\title{
PROLOGUE AND EPILOGUE. THE SOCIO-ECONOMIC EFFECT OF ROME'S ARRIVAL IN AND DEPARTURE FROM GAUL By \\ JOHN F. DRINKWATER*
}

Our subject is 'the transformation of economic life under the Roman Empire', as part of a general consideration of 'the impact of Empire'. This paper derives from my disquiet over the use of the words 'impact' and 'transformation' in describing the socio-economic relationship between Rome and her provinces, and over too narrow a chronological delimitation of the discussion of this relationship. I deal with the first under 'Prologue' and the second, necessarily briefly, under 'Epilogue'.

\section{Prologue}

'Impact' and 'transformation' occur frequently in this context in all the major languages of scholarship, ${ }^{1}$ and appear generally to be used as synonyms for the effect that the Roman Empire had on subject societies. 'Effect' may be represented graphically as in Fig. 1. However, human societies are not static, and the same situation is better represented as

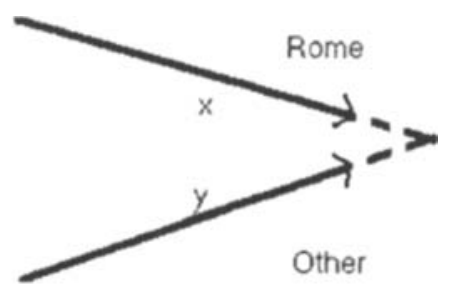

Fig. 2

shown in Fig. 2. Here, the two arrows represent movement, as a pair of societies, $x$ (Roman) and $y$ (nonRoman), develop individually while approaching each other in space and time, the main effect of $x$ on $y$ being at the projected point of intersection.

This representation is further developed in Fig. 3, where I

\footnotetext{
- I must thank Professor John Collis, Department of Archaeology and Prehistory, University of Sheffield, for helping me with important aspects of this paper.

' J. F. Drinkwater, Roman Gaul. The Three Provinces, 58 B.C.-A.D. 250 (London/Canberra 1983), Ch. 6 ("The impact of the army"); M. Py, Les gaulois du Midi. De la fin de l'Âge du Bronze à la conquête romaine (Paris 1993), 123 discusses the "impact of transformations"; and N. Roymans, "The sword or the plough. Regional dynamics in the romanisation of Belgic Gaul and the Rhineland area', in N. Roymans, ed., From the Sword to the Plough (Amsterdam 1996), 99, uses "transformation" in tandem with "reformulation".
} 
tentatively label the main forces determining the trajectories of $x$ and $y$ as 'mass' ( $m$ : how developed each is), 'velocity' ( $v$ : how quickly each is developing) and 'direction' ( $d$ : how likely both are to come into contact with each other). At the point of intersection, the fate of $x$ and $y$ will depend on their relative socioeconomic, political and military robustness. Therefore in Fig. $4 \mathrm{I}$ add another variable, $c$ : 'composition'.

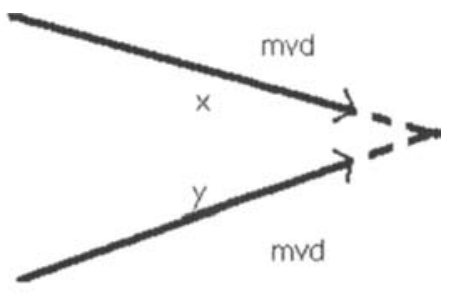

This treatment suggests that the relationship of $x$ and $y$ might be capable of mathematical modelling. Calculation of the forces involved in the convergence of two or more bodies is possible using 'vector' or 'scalar' analysis. It is employed, for example, by experts investigating collisions between vehicles. In this field, unknowns can be safely deduced from

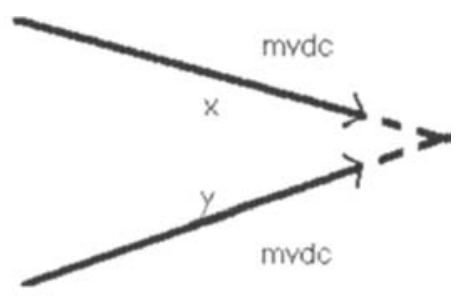

Fig. 4 knowns, e.g. the speed of vehicles concerned from the damage each has sustained.

However, these sorts of calculations are not available to social historians, especially those of the ancient world. The variables are infinite; and anyway we have neither the data nor the mathematics to process them. So where do such considerations take us in respect of the history of the Roman Empire? I propose that they produce three axioms that should be taken into account in more orthodox study:

1) The investigation of 'impact' or 'transformation' is not possible without some knowledge of the state of both bodies involved. In other words, it is unsound to discuss the impact of the Roman Empire on a society without first establishing, as a base line, the economic, social and political characteristics of that society at the point of contact, and indeed perhaps without considering how that society might have developed had there been no direct contact. In short, ideally we should start by consulting Hellenistic historians and Iron Age archaeologists. 
2) In certain cases, 'contact' might not amount to 'impact'. With reference to my earlier propositions, if $(\mathrm{mvdc}) x$ and $(\mathrm{mvdc}) y$ are broadly similar, i.e. if a diagram of forces resembles that in Fig. 5, where angle ' $a$ ' is relatively acute, then surely we should be talking about 'convergence', not collision or total change. Strong words, such as 'impact' and 'transformation', should be reserved for other, more powerful and dramatic types of interaction.

3) Finally, whether we are dealing with convergence or impact, the notion of a point of intersection reminds us that we have to try to establish a specific date, or at least period, for the events we are attempting to understand, i.e. we have to say precisely which 'Roman Empire' we have in mind:

a) The one that comprised the Italian peninsula south of the Apennines - in existence c. 270 B.C.?

b) The one that comprised roughly modern Italy, including land north of the Apennines, and the surrounding islands-in existence by c. 220 B.C.?

c) The one that gave Rome hegemony over the western Mediterranean region-in existence by c. 200 B.C.?

d) The one that gave Rome hegemony over the entire Mediterranean region-in existence by $c$. 60 B.C.?

e) The one which had its frontiers on the Rhine and Danube-in existence by the end of the first century B.C.?

f) Or some other?

It is plainly impossible to pursue all these concerns in respect of the whole of the Roman Empire within a short paper. In what follows I will, therefore, by way of example, consider them with regard to Gaul. And even here, because of the size and complexity of the subject, and because I am no prehistorian, I will adopt a very broad approach.

From the start I have to state frankly that for the most part we appear to be in the presence of convergence rather than collision. In general terms, the most important changes in Gallic society had taken place long before the arrival of Rome. In particular, by the end of the Bronze Age there had occurred the crucial agricultural revolution that led to the clearing of much 
of the forest and to the establishment of a successful mixed agriculture which, though still basically subsistence-orientated, was capable of innovation and expansion. It was able to sustain a relatively large population, among which was developing significant economic and social specialisation. The process was not uniform, and there were setbacks, for example consequent upon the still mysterious transformation of the Hallstatt culture. ${ }^{2}$ But Gallic Iron Age society was resilient and, overall, continued to move towards a sophisticated pre-industrial economy. In addition, we have to remember that this society, unlike that, say, of Germany or Britain, was open to direct stimulation from the older cultures of the Mediterranean, Etruscan, Punic and Greek. It is surely reasonable to suppose that an advanced culture would have developed in Gaul had Rome never existed. Roman Gaul was not created $a b$ initio, but was built on substantial pre-Roman foundations.

Acceptance of convergence rather than collision is implicit in most modern studies of western provincial life. Indeed, it lies at the heart of recent re-interpretations of Romanisation, no longer seen as a fixed pattern, imposed from the imperial centre, but as an infinitely variable design, determined at local level by (to use the current jargon) 'dialogue', 'negotiation', between the participating cultures, native and foreign. ${ }^{3}$ As I have already said, it seems to me that archaeologists and historians use such words as 'impact' and 'transformation' when they really mean interaction and natural change.

Let us move to specific areas of study. This interpretation is familiar in the excellent work being done by Dutch and British archaeologists on northern Gaul. I cite the recent, reliable and deservedly acclaimed collection of papers edited by Nico Roymans. ${ }^{4}$ In his own contribution, Roymans reconstructs Late Iron Age society in Caesar's Belgica. In one way this society appears primitive, because predominantly pastoral and martial, its products probably changing hands more by gift-exchange and raiding than by trade. ${ }^{5}$ However, underneath Roymans detects major technological advances resulting in greater agricultural productivity, a

${ }^{2}$ B. Cunliffe, Greeks, Romans and Barbarians (London/New York 1988), 33-35; cf. C. Haselgrove, 'Roman impact on rural settlement and society in southern Picardy', in Roymans, ed., 1996, op. cit. (n. 1), 140.

${ }^{3}$ Cf. Roymans 1996, art. cit. (n. 1), 99, 103: "creative interpretation"; an "articulation" of native and Roman values. Cf. most recently J. Webster, 'Creolizing the Roman provinces', American Journal of Archaeology 105 (2001), 209-225.

${ }^{4}$ Roymans 1996, op. cit. (n.1).

${ }^{5}$ Roymans 1996, art. cit. (n.1), 44-47. 
significant rise in population, increasing economic specialisation and a more complex social hierarchy. ${ }^{6}$ While in the north of the region farming remained pastoral and to some degree peripatetic, in the south it became more arable, its settlements becoming more nucleated and permanent. ${ }^{7}$ Rome simply took over and exploited these developments. Southern Belgica became a region of villas and towns, growing wealthy by supplying cereals to the Roman army on the Rhine. ${ }^{8}$ In contrast, northern Belgica continued its pastoral and military tradition, providing live beasts, animal products and fighting-men to the Rhineland forts and settlements. ${ }^{9}$ There was change, but this should be interpreted as an intensification of existing lines of development, going with the grain of native values and aspirations, rather than as anything entirely novel or disruptive. ${ }^{10}$ As Roymans says of those in the north:

These changes, however, mainly represent autonomous native developments which began in the Late Iron Age; for this reason they cannot be considered products of 'romanisation'. ${ }^{11}$

In the same volume, Colin Haselgrove depicts the development of a particular set of rich arable lands in the south of Roymans' study-area, in the Aisne valley, in almost identical terms. By the Late Iron Age, i.e. the second century B.C., good soil, an improving climate and advances in tooltechnology and farming-techniques had produced a rising population, "which laid the foundation for subsequent developments". ${ }^{12}$ Since the title of Haselgrove's paper is 'Roman impact on rural settlement and society in southern Picardy', it is hardly surprising that he proceeds to show how these "subsequent developments" included strong elements of change. Rome's arrival in southern Gaul in the second century B.C. caused political and military tension further north, precipitating, inter alia, the widespread construction of oppida; ${ }^{13}$ and the Roman conquest of the north was

\footnotetext{
${ }^{6}$ Ibid., 49-50, 53.

${ }^{7}$ Ibid., 51-55 (pastoral), 55-58 (arable).

${ }^{8}$ Ibid., 58-72.

${ }^{9}$ Ibid., 72-84, 86-87.

10 'Intensification': used by Roymans 1996, art. cit. (n.1), 63, in respect of villas, but from what he says at 61-72, generally applicable to developments in the region; cf. 99. For 'grain' see ibid., 87-88.

11 Ibid., 83.

${ }^{12}$ Haselgrove 1996, art. cit. (n.2), 146.

${ }^{13}$ Ibid., 147-52; 164.
} 
followed by the 'Romanisation' of the region. ${ }^{14}$ On the other hand, however, Haselgrove is also at pains to point out the vitality of the indigenous culture, and significant continuities from the Iron Age to the Roman period, for example the design of the Belgic courtyard-villa, and even the operation of the taxation-system. ${ }^{15} \mathrm{He}$ concludes:

In practice, indigenous developments during the later Iron Age were far more significant than Mediterranean contacts in providing a base on which Roman institutions could later flourish ... ${ }^{16}$

This society had a dynamism of its own which allowed it to interact with, rather than be crushed by, the more (though, in absolute terms, not very much more) advanced cultures from the south. Again, it is surely possible to hold that much of what happened in the 'Gallo-Roman' Aisne valley would have happened anyway, Rome or no Rome, as Gaul was drawn increasingly into Mediterranean life.

Mention of the Mediterranean takes us to an arguably even more important area, southern Gaul, 'the Province', the modern regions of Provence and the Languedoc. Recent years have seen a welcome tendency for scholars working in these areas to collate and assess the massive amount of archaeological data available for study. Here, I refer particularly to books by Michel Py and Bert Freyberger. ${ }^{17}$

According to Py, agricultural revolution in this region occurred very early, with extensive de-forestation being practised from the late Neolithic period. By the Iron Age the landscape was very much as we see it today. ${ }^{18}$ By the end of the Bronze Age there was developing a mixed-arable and pastoral-agriculture, which was being stimulated by the adoption of new tool-materials and farming-techniques and new varieties of crops. ${ }^{19}$ These advances were associated with a rise in population, and the beginning of skill-specialisations and a social hierarchy. ${ }^{20}$ From the seventh century B.C. this indigenous development was accelerated by the area's first significant contact with developed Mediterranean cultures-principally Etruscan,

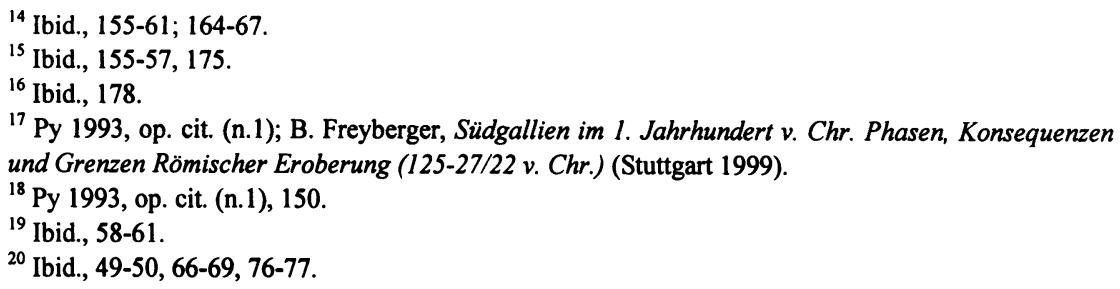


Greek and Iberian. However, Py stresses the continuity of native ways, and of interaction, as the indigenous population chose from what was on offer. Specifically in respect of the arrival of Classical culture, he refers to a 'dialectic process' between newcomers and original inhabitants, reflected, for example, especially (or even) in the urbanisation of the littoral. ${ }^{21}$ Overall there was change, sometimes great change, as the area moved from subsistence to market production. ${ }^{22}$ However, such change was slow, uneven over space and time, and always embedded in previous practice. ${ }^{23}$ It may be regarded as resulting from the catalysation, not the transformation, of local ways by outside cultures. It was evolutionary, not revolutionary; we should think of 'debarbarisation' rather than Hellenisation, since what came about was not a new culture but rather a new stage in the development of the old. ${ }^{24}$ And, again, Rome was able to build on earlier developments. ${ }^{25}$ According to $\mathrm{Py}$, a flourishing indigenous society, reacting to, keeping pace with and even, in some respects, gaining on, Mediterranean culture, persisted in southern Gaul until the reign of Augustus. ${ }^{26}$

We find Py's arguments recently taken up and developed in detail by Freyberger, with regard to the early Roman period. He agrees that there was a flourishing indigenous culture in southern Gaul at the time of the Roman conquest of the area, from 125 B.C. ${ }^{27}$ Records of native unrest under Roman rule, and Cicero's picture of a country overrun by outside traders, though not untrue, tell only part of the story. ${ }^{28}$ Archaeological evidence suggests a remarkable resilience and continuity in almost every aspect of life, urban and rural, from coins to religion. ${ }^{29}$ Freyberger attributes Roman laissez-faire in respect of the region to political expediency (including, down to 49 B.C., respect for the sphere of influence of Marseille) ${ }^{30}$ However, whatever the cause, we seem again to be in the presence of evolution, not revolution, of convergence, not impact, of organic change, not transformation.

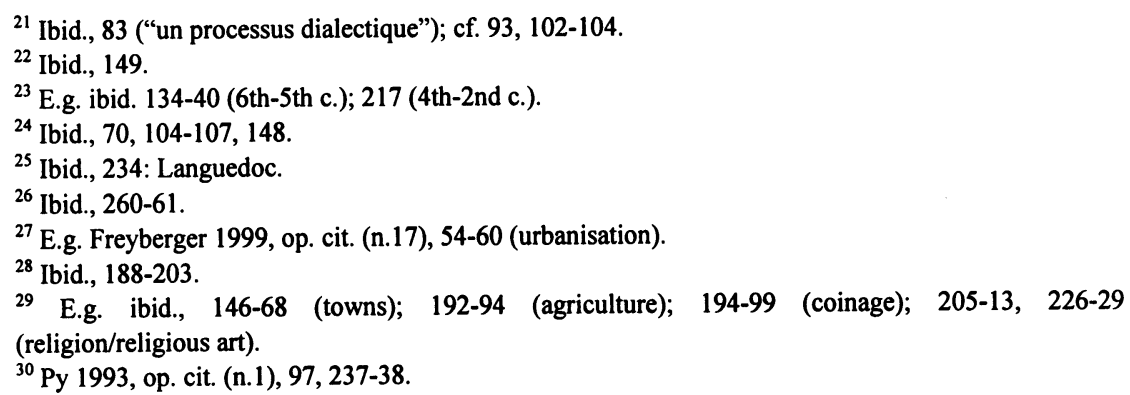


Therefore, given this general trend of convergence, may we in any way talk of a Roman 'impact' on, a Roman 'transformation' of, Gallic society or the Gallic economy? I believe that we can, and that a close understanding of what this was allows us to resolve the third of the issues I raised at the start of this paper: the question as to which Roman Empire we are talking about here.

The key to such understanding is to decide what we are looking for. Again as I said near the start of this paper, this should not be the ordinary but the extraordinary, the dramatic: that which need not have happened, but which in happening had immense consequences. I attempt to represent such a situation in Fig. 6. Here, the vectors are shown diverted by a sudden change in direction of one of the participating bodies.

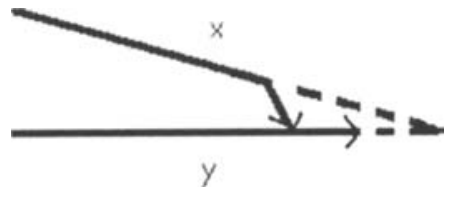

Fig. 6.

It might be thought that such a phenomenon is characteristic of wars of conquest, but I would disagree. This was clearly not so in the case of southern Gaul, where, as we have seen, conquest was followed by a remarkably long period of continuity. But it was also not the case in respect of the much more extensive and destructive conquest of northern Gaul by Julius Caesar. His bloody wars were followed by almost a generation of little change during which, among other things, the surviving tribal leaders simply switched their loyalty to another great chief. ${ }^{31}$ As Py remarks, we must not exaggerate the effect of war on such societies. ${ }^{32}$ It was part of life; both sides knew the rules, and losers had simply to live with the consequences. We must also bear in mind that the fragmented nature of Gallic society would have prevented those involved from seeing the wider picture. None of Caesar's vanquished foes could have fretted about the fact that their defeat marked the end of 'the late La Tène' in Gaul. As far as they were concerned, they, among other tribespeople, had been overcome by one mighty chief and his tribe, whom they were, under their own customs of war, now bound to follow. ${ }^{33}$ My contention is that Gaul was impacted upon and transformed by something related to these wars, but different from them: the institution of the Principate and, so, by the Augustan Empire.

\footnotetext{
${ }^{31}$ Drinkwater 1983, op. cit. (n.1), 18-20.

${ }^{32}$ Py 1993, op. cit. (n.1), 241, 262.

${ }^{33}$ Drinkwater 1983, op. cit. (n.1), 26 (Germanicus as 'chief').
} 
Here I must emphasise that my point is not simply that Augustus' policies precipitated major change in Gaul. Such a proposition would hardly be new; and in this respect, of course, Gaul was not alone among the imperial provinces. My aim is rather to bring out the particular role that Gaul was made to play in the operation of a very curious system and, through this, to reach a closer understanding of the history of both the region and the office of 'emperor'.

Both Py and Freyberger agree that from 27 B.C. Augustus' decisions in respect of southern Gaul had immediate and decisive effects on its development. According to Py, it was with Augustus that the 'protohistory' of the region finally came to an end. ${ }^{34}$ Freyberger, even more forcefully, argues that major change came to the region with the mass of colonies, veteran and Latin, founded by Caesar and Augustus and, in particular, with the latter's encouragement of the full-scale monumental urbanisation of the region as an essential element in his publicisation of his 'New Order'. ${ }^{35}$ Allowing for some time-lag, to cover the deployment of the expertise and materials required to implement such changes across a huge country, much the same may be said for the rest of Gaul. ${ }^{36}$ However, this is not what I wish to examine here. My subject is, rather, Gaul and the Principate.

We should begin by asking some basic questions. Why was Augustus so interested in Gaul? Why did he give the country so much of his attention? Why, with regard to Augustus and his immediate successors, is it possible to talk of a 'special relationship' between Gaul and the ruling dynasty $?^{37}$ The short answer is, of course, that Augustus was interested in Gaul because Julius Caesar had been interested in it: Gaul was part of his political inheritance, of the Julian clientela. In one way this response is unhelpful, simply pushing the issue back one generation. In another way, however, it suggests a more interesting answer. Caesar was interested in Gaul because his wars there enabled him to acquire sufficient military renown, wealth and military strength to take over the Roman state. Similarly, we might say, from 44 B.C. Octavian was interested in Gaul because it provided military strength to help him establish his claim to be Caesar's sole political heir. Finally, from 27 B.C. Octavian-becomeAugustus continued this interest because Gaul played a unique role in helping him maintain his new position of princeps.

\footnotetext{
${ }^{34}$ Py 1993, op. cit. (n.1), 259.

${ }^{35}$ Freyberger 1999, op. cit. (n.17), 97-99, 121-38.

${ }^{36}$ Drinkwater 1983, op. cit. (n.1), 189-90.

${ }^{37}$ Cf. ibid., 20, 25, 27, 35.
} 
The existence of a permanent Roman army is something that we take for granted. Indeed, since Gibbon, we have become accustomed to admiring the economy of force deployed: so few men defending so much territory. ${ }^{38}$ However, Romans of the late Empire grumbled about the burden it represented; and we should ask what this army was defending the Roman Empire against. Here, again, I concern myself only with Gaul, where the answer seems clear-against Germanic invaders. However, I now believe that it can be demonstrated that throughout the imperial period the 'Germanic threat' was illusory. ${ }^{39}$ The Germanic tribes produced troublesome, at times very troublesome, raiders, but from beginning to end there were never any massed hordes of potential invaders constantly pressing against the frontiers. Most aggression was on the Roman side. ${ }^{40}$ So, again, why were there so many troops in Gaul, in particular under the Julio-Claudians? Tacitus, writing somewhat later and, perhaps, sensing the problem, famously observed that the Roman army on the Rhine faced in two directions: outwards, against the Germanic peoples, and inwards, to keep an eye on the Gauls. ${ }^{41}$ This could be true; relations between Romans and Gauls were always somewhat strained. ${ }^{42}$ However, it seems to me to be only part of the answer, and that the rest lies in the requirements of the Principate.

As is well enough recognised, this was a wonderful political sleight of hand. However, it was not the only way out of Rome's problems. The disappearance of the Republic could have had various outcomes, including the partition or even the disintegration of the Republican Empire. Augustus' invention of the Principate was not the most obvious solution, and it was to cause problems for centuries to come; but it worked. Its success depended on many factors, but of major importance among these was military backing. The newly legitimised warlord could not risk his personal safety and the continuance of his power by fully demobilising his forces. He needed a standing army. Of course, he gave himself the Praetorian Guard, but to begin with this was relatively small, dispersed and, perhaps, not

\footnotetext{
${ }^{38}$ E. Gibbon, The History of the Decline and Fall of the Roman Empire, vol. 1 (London 1900, ed. J. B. Bury), 18.

${ }^{39}$ I.e. contrary to Drinkwater 1983, op. cit. (n.1), 120, 122.

${ }^{40}$ See most recently J. F. Drinkwater, 'Ammianus, Valentinian, and the Rhine Germans', in J. W. Drijvers and D. Hunt, eds., The Late Roman World and Its Historian. Interpreting Ammianus Marcellinus (London 1999), 127-37. Cf. W. Pohl, Die Germanen (Munich, 2000), 13-15, 18, 25.

${ }^{41}$ Tacitus, Annales 4.5.2: commune in Germanos Gallosque subsidium.

${ }^{42}$ See e.g. Drinkwater 1983, op. cit. (n.1), 48-9.
} 
regarded as entirely legitimate. ${ }^{43}$ Augustus therefore required a substantial force of regular legions, relatively close to hand.

I propose that Augustus made Gaul a reservoir of military strength to support his position. (The abortive advance into Germany, from 12 B.C. to A.D.9, may be regarded as an unforeseen consequence of this strategy. ${ }^{44}$ ) Troops stationed in Gaul did not offend the Roman tradition that was still solidly against the garrisoning of Italy; and they were not feeding off Italy. However, they were close to Italy and could be called upon (or, simply, alluded to) as necessary. In other words, I suggest that Gaul was essentially militarised by Augustus, and that it was this militarisation - seen first in the planting of more colonies in the south and then in the movement of troops to the Rhine frontier, and their maintenance there-that 'impacted' on Gaul, that 'transformed' the economy and society of the country, in ways that would not have come about under the 'normal' evolutionary process.

The army on the Rhine was surely what made Gaul special in Roman imperial history, and gave it its distinctive character. The need to chronicle the activities of the Rhine garrison is why we have so much about the region in the literary sources, from Tacitus to Zosimus. It was the presence of this garrison that fired-up the Gallic economy. The Rhine troops, and their various dependants, provided the markets for the northern farmers and the southern and Mediterranean traders. As I have said elsewhere, if the Rhône was the flue of Gallic trade, it was the Rhine army that generated its massive upward draught. ${ }^{45}$ The same force also gave Gaul its shape and meaning. The functioning of Gaul as a single unit is best seen in the activities of western usurpers. These, having won the backing of the Rhine troops were, as a matter of course, immediately recognised throughout the country, and so immediately gained the tax-base on which to support their military and political strength. ${ }^{46}$ When the Rhine army disappeared during the first half of the fifth century, Gaul as a meaningful geo-political entity went with it: "One either held all of Gaul, or none of it. There was nothing to be gained by trying to hang on to bits [sc. of it]. ${ }^{, 47}$

\footnotetext{
${ }^{43} O C D^{3} 1241$.

${ }^{44}$ Pohl 2000, op. cit. (n. 40), 95.

${ }^{45}$ Drinkwater 1983, op. cit. (n.1), 129.

${ }^{46} \mathrm{Cf}$. Tacitus, Annales 1.47.2: the Rhine army "depended upon the riches of Gaul" (Galliarum opibus subnixus).

${ }^{47} \mathrm{H}$. Elton, 'Defence in fifth-century Gaul', in J. F. Drinkwater and H. Elton, eds., Fifth-Century Gaul: A Crisis of Identity? (Cambridge 1992), 172, with Drinkwater and Elton, ibid., 320.
} 


\section{Epilogue}

This takes us to the end of the Roman period in Gaul, and to my promised Epilogue. Everything has a beginning and an end. Empires change and impact upon other cultures when they are growing. However, it should not be forgotten that they also affect other cultures when they are shrinking. I suggest that in any discussion of the 'Impact of Empire' or the 'transformation' of provincial economies and societies this feature of imperial development should also be given attention. I offer, by way of example, an aspect of Alamannic history.

The militarisation of Gaul, stimulated by the institution of the Principate, persisted as a matter of policy, and then as one of habit and convenience. Gaul remained a useful place to 'park' imperial troops, and to win military glory. The western Germanic peoples helpfully confirmed Rome's professed justification for keeping large forces on the Rhine by raiding into the Empire when it was distracted by civil war. This situation changed in the fifth century, when Visigoths, Burgundians, Alans and Franks were allowed to settle west of the Rhine. The old frontier lost its significance; Gaul disappeared piecemeal. However, recent archaeological study has shown that a Roman presence on the river was maintained to around 450 , by garrisons of Germanic federates. On the upper and middle Rhine these comprised Alamanni, who had settled on former imperial territory in Upper Germany and Raetia from the later third century. During the fourth century, local Alamannic chiefs developed a distinct lifestyle, founded on Roman military service. Living on Roman pay, subsidies and, no doubt, booty taken during Roman campaigns, they led a heroic existence on imposing hill-settlements. Few of the goods they imported from the Empire or had made by Empire-trained craftsmen made their way to Alamannic rural sites. This suggests little contact with, interest in, or development of local agriculture: the Alamannic ruling class were economic parasites. Final Roman disengagement, and so the ending of pay and subsidies, after 450 must therefore have come as a great shock, and must have impacted considerably on the way of life of such people. I propose that this can be seen in the archaeological record. Finds of rich grave-goods, in particular of gold-handled long-swords, appear to indicate that in the later part of the fifth century there was, for the first time, intense aristocratic 
interest in the rich farmlands of the middle and upper Neckar valley. ${ }^{48} \mathrm{I}$ suggest that this may be interpreted as the Alamannic aristocracy's falling back on native agricultural resources to fill the gap left by the withdrawal of Roman pay: economic transformation caused by the end of empire.

Nottingham, July 2001

\footnotetext{
${ }^{48}$ H. Steuer, 'Herrschaft von der Hőhe. Vom mobilen Söldnertrupp zur Residenz auf repräsentativen Bergkuppen', in Die Alamannen (Archăologisches Landesmuseum Baden-Württemberg) (Stuttgart 1997), 153, 157-60, and fig. 160 (distribution of swords and 'Bügelfibeln'). Steuer appears to come close to my interpretation, but nowhere states it explicitly.
} 